\title{
Effects of Mass Media in Sports
}

\author{
Ika Novitaria Marani \\ Faculty of Sport Science \\ Universitas Negeri Jakarta \\ Jakarta, Indonesia \\ ika.novitaria@unj.ac.id \\ Eva Yulianti \\ Faculty of Sport Science \\ Universitas Negeri Jakarta \\ Jakarta, Indonesia \\ eyulianti@unj.ac.id
}

\author{
Rhewindinar \\ line 2: dept. name of organization \\ (of Affiliation) \\ Universitas Bunda Mulia \\ Jakarta, Indonesia \\ rewindinar@gmail.com \\ Ari Subarkah \\ Faculty of Sport Science \\ Universitas Negeri Jakarta \\ Jakarta, Indonesia \\ arisubarkah@unj.ac.id
}

\author{
Heni Widyaningsih \\ Faculty of Sport Science \\ Universitas Negeri Jakarta \\ Jakarta, Indonesia \\ heniwidyaningsih@unj.ac.id \\ Mansur Jauhari \\ Faculty of Sport Science \\ Universitas Negeri Jakarta \\ Jakarta, Indonesia \\ mansur.jauhari@unj.ac.id
}

\begin{abstract}
Mass media is a tool in communication that can spread, shape and influence the message or information conveyed. The message conveyed will have a different effect depending on the media used. Therefore, this study aims to determine the effect of the mass media on sports performance in Indonesian badminton athletes. The research instrument used a questionnaire and distributed it to Indonesian national badminton athletes. The data analysis technique used SPSS to calculate the moment product correlation and simple regression from 49 data of Indonesian national badminton players. The results showed that the mass media had an effect on sports achievement by $41 \%$. The correlation coefficient between mass media and sports achievement is 0.64 . The conclusion is that with the rapid development of mass communication technology and mass media, the media not only change or strengthen opinions, attitudes and behavior, but have become one of the agents of socialization in creating and shaping attitudes, values, behaviors and perceptions of social reality.
\end{abstract}

Keywords-Media Massa, Sport

\section{INTRODUCTION}

Sport refers to enjoyable self-development, self-actualization, and competitive use of physical and mental skills. People are familiar with sports activities such as: running, swimming, wrestling, badminton, football, etc. So it's not surprising that players and sports fans find sports very interesting. The development of sports from prehistoric times to the present is a function of industrialization, modernization and telecommunications [1]. Sport reflects social values that can extend from individual values such as: discipline, sportsmanship, productivity, competitive advantage and others. Sport is also an integrative element that can build an image for individuals and the whole society. Where, society can act as a unifying force and a strong factor of socialization, increasing social acceptance and fans of athletes. Sport can also support social and cultural identity as well as the construction of national identity [2].

One way to provide an understanding to the public about sports by providing a narrative that can influence the public about the concept of sport is the media [3]. Because the concept of the media is as a source of information about recent events that can arouse a growing interest such as sports [4]. The information or message conveyed is developed according to the criteria of actuality, objectivity and simplicity with the aim of producing a message with the widest possible reach. In other words, what is defined as "newsworthy" content in sports is governed by those criteria $[5,6]$.

The media is an important instrument because the media can tell, teach, see communal problems and replicate social principles. One of the communal phenomena experiencing urbanization is sport. The role of the media in sports as a source of entertainment. Because sporting events have all elements of entertainment as pleasant phenomena, such as rituals (playing the national anthem and introduction of the players), the tension that occurs in the game, the existence of conflict, uncertainty about victory or failure, mental pleasure stimulated by unexpected tactics and new strategy [7]. Therefore, the audience's level of interest in sports is getting higher which can be done through various types of media.

Mass media is a tool used for mass communication or communication on a large scale. This term includes the press, cinema, radio and television as well as books, posters, recorded music and other media that circulate in large numbers [8]. Based on many studies, it is stated that the carrier of information and the way of conveying information 
from the mass media have a stronger effect on those who receive information. The emergence of mass society depends on the development of new technologies and new technical tools used to convey information to a wide audience [9].

There are several studies of mass media and sports including the role of the media in reproducing, maintaining and creating "imaginary communities". [10]. There is also research by surveying how to represent sport - both reactionary and resistance [11]. And there is also research that studies the effects of mass media on exercise. The results showed that mass media and sports are two domains that influence each other and each changes because of one another, or it can be said that mass media and sports form an almost perfect unity. [12].

The availability of means of communication with different channels but used simultaneously to share information has an advantage. An important aspect of digital culture is increasing consumer extreme interest in media content which can have an unquestionably large influence in a number of different areas, known as the "hostile media effect". $[13,14]$. There are several studies that identify the impact of sports coverage in the mass media on the audience that causes the modern culture and communication industry to continue to grow $[15,16]$. With the advent of social networks, it is possible for journalists from different media groups to publish sports information diligently. Thus, journalists can contact spectators or sports players to be able to get news and have a greater influence on both spectators and sports players or athletes. [17].

Although the media get interesting information to express, disseminate and provide opinions from the media itself using other perspectives, the content that can be disseminated by the media is still limited. [18, 19]. Therefore, we are under the influence of forces that we cannot see or realize their influence on our behavior and attitudes. This power is symbolic culture, especially mass media that has become a part of our lives [20]. The main disadvantage of publishing sports news in the media is that the news delivered to readers is delayed for quite a long time when a sporting event has ended [21]. Based on the above study, we are aware of the clear role of the mass media in sports, namely in righteous beliefs, attitudes and communal opinions and creating an optimistic place in sport. Thus, the purpose of this study was to determine the effect of mass media on sports from a competitive sport perspective with the aim of achieving optimal sports performance.

\section{METHODS}

This study aims to test the research hypothesis, namely whether there is an influence of mass media on sports in Indonesian badminton national athletes. The research method used in this research is associative research that wants to find out the effect of mass media on sports. The population in this study were all Indonesian national badminton athletes, totaling 64 people. The sampling technique used in this study is purposive sampling with the consideration that the badminton national athlete is in the top 50 in the world. So that the sample used in this study amounted to 49 people consisting of 25 men and 24 women Indonesian badminton national athletes. The selection of badminton athletes who became the population and sample in this study because badminton is one of the sports in Indonesia that has proud achievements to the world level and badminton has the most enthusiasts and fans in Indonesia.

The population in this study were all Indonesian national badminton athletes, totaling 64 people. The sampling technique used in this study is purposive sampling with the consideration that the badminton national athlete is in the top 50 in the world. So that the sample used in this study amounted to 49 people. The selection of badminton athletes who became the population and sample in this study because badminton is one of the sports in Indonesia that has proud achievements to the world level and badminton has the most enthusiasts and fans in Indonesia.

This study uses two test instruments, namely an instrument test to measure the effects of mass media and a test instrument to measure the performance of Indonesian badminton national athletes. The operational definition of mass media in this study is how to measure the effects of mass media on individuals. Because the focus of the mass media is the message, the effect must be related to the message conveyed by the mass media. Therefore, the mass media instrument has 3 indicators, namely: cognitive effects, affective effects, behavioral effects. The measurement uses a questionnaire with a Likert scale which has 4 answer options, namely: Strongly agree (SS), Agree (S), Disagree (TS) and Strongly Disagree (STS). Questionnaires were given to all Indonesian badminton national athletes who were sampled in this study. As for the instrument test, the performance of badminton national athletes is assessed by using the results of matches that are followed for 1 year. The results of the championship are given a score according to the level or level of the championship that the player participates in. The championships that are calculated in the athlete's performance test are: BWF Super Series Final, Super Series, Grand Prix Gold, Grand Prix, International Challenge, and International Series championships. 


\section{RESULTS AND DISCUSSION}

Description of the data from the results of the study which aims to provide a general description of the distribution of data in the form of the size of the location of the frequency distribution, namely the average, maximum value, minimum value, standard deviation, mode, median. The data that is generated is based on the results of the tests that are studied in this study, namely: the effects of mass media and sports achievement. The description of the data from the results of the study is presented in the table below.

Table 1. Description of research results

\begin{tabular}{lcc}
\hline \multicolumn{1}{c}{ Description } & $\begin{array}{c}\text { Mass } \\
\text { Media }\end{array}$ & $\begin{array}{c}\text { Sport } \\
\text { Performance }\end{array}$ \\
\hline Minimum & 97 & 3 \\
Maximum & 125 & 97 \\
Mean & 108.16 & 44.33 \\
Median & 107 & 34 \\
Modus & 106 & 97 \\
Standar Deviation & 6.12 & 28.81 \\
Varians & 37.47 & 830.14 \\
\hline
\end{tabular}

The following shows the results of the calculation of the effect of mass media on sports achievement.

Table 2. Calculation of Correlation Coefficient

\begin{tabular}{|c|c|c|c|c|c|c|}
\hline \multicolumn{7}{|c|}{ Model Summary } \\
\hline \multirow[b]{2}{*}{$\begin{array}{c}\text { Mode } \\
1\end{array}$} & \multirow[b]{2}{*}{$\mathrm{R}$} & \multirow[b]{2}{*}{ R Square } & \multicolumn{4}{|c|}{ Change Statistics } \\
\hline & & & $\begin{array}{c}\mathrm{F} \\
\text { Change }\end{array}$ & df1 & df2 & $\begin{array}{c}\text { Sig. F } \\
\text { Change }\end{array}$ \\
\hline 1 & $.064^{\mathrm{a}}$ & .409 & .194 & 1 & 47 & .0 .050 \\
\hline
\end{tabular}

Table 3. Correlation Coefficient Significance Test

\begin{tabular}{|c|c|c|c|c|c|}
\hline \multicolumn{6}{|c|}{ Coefficients $^{\mathrm{a}}$} \\
\hline \multirow[b]{2}{*}{ Model } & \multicolumn{2}{|c|}{$\begin{array}{l}\text { Unstandardized } \\
\text { Coefficients }\end{array}$} & \multirow{2}{*}{$\begin{array}{c}\text { Standardize } \\
\text { d } \\
\text { Coefficients } \\
\text { Beta }\end{array}$} & \multirow[t]{2}{*}{$\mathrm{t}$} & \multirow[t]{2}{*}{ Sig. } \\
\hline & $\mathrm{B}$ & Std. Error & & & \\
\hline (Constant) & 10.76 & 1.630 & & 6.59 & $\begin{array}{r}.00 \\
0\end{array}$ \\
\hline $\begin{array}{l}\text { Prestasi } \\
\text { Olahraga }\end{array}$ & .14 & .031 & .064 & .040 & $\begin{array}{r}.05 \\
2\end{array}$ \\
\hline
\end{tabular}

The table data above shows that the research hypothesis which states that there is an effect of mass media on sports achievement is accepted. This is indicated by the value of the correlation coefficient $\mathrm{RX}_{1} \mathrm{Y}=0.64$. From the test of the significance of the correlation coefficient, it can be seen that tcount $=$ $6.59>$ from ttable $=1.701$ it means that the correlation coefficient $\mathrm{ry}_{1}=0.64$ is significant or significant. The coefficient of determination of the mass media with sports achievement $\left(\mathrm{ry}_{1}{ }^{2}\right)=0.41$. This means that the mass media has a contribution to sports achievement by $41 \%$ and $59 \%$ is influenced by other factors.

The results of statistical calculations show that $t_{\text {count }}=6.59>$ from $t_{\text {table }}=1.701$. This shows that there is an effect of mass media on sports achievement. This is because the mass media can change people's behavior either directly or indirectly [22]. Because the mass media can produce, communicate so that it can cause changes in the way people think [12]. This paper aims to test the hypothesis which states that there is an effect of mass media on sports achievement.

The media plays an important role in relation to sports. This can be seen by the increasing public interest in sports over the last two decades due to the development and increasing influence of the media [23]. In addition, the development of modern sports, the birth of consumer culture and the creation of markets began to emerge simultaneously in the late 19th and early 20th centuries. [24]. Sports have been presented, represented in different ways by the media, where the media in turn are always subject to a form of regulation.

Sport is a fundamental instrument of the contemporary media industry. Where the availability of the athlete's image and personality during competitions and the arrangement of individual representations and their social life becomes something that cannot be avoided by the spotlight of the masses [25]. Mass media has a very vital role in boosting every sporting activity. On the one hand, sport can influence education and training, social practice and even build individual cultural identities and values, while on the other hand the media produce, reproduce, disseminate information, interpret events and provide explanations and meanings to the public so that they can construct knowledge and public understanding of various things [26].

Sport has a positive relationship with the media, because sport is an integral part of the successful component of social communication. By having a complementary relationship, where sport needs a medium for publicity and sports approach to society so that sport can develop and project itself as a social practice and media need sport to increase the number of viewers. [27]. The media can influence the popularity of sports, provide free publicity to sports players or teams, and showcase the athlete's personality and build fan loyalty to the team or individual athlete. So it can be said that there is a symbiotic relationship between media and sports. Because both sports and mass media both seek to reach people as spectators, fans and consumers [28]. 
In the communication process, messages in the mass media can befall someone either directly or indirectly. Effects are only changes in human behavior after being hit by mass media messages [29]. Because the focus in communication is the message, the effect must be related to the message conveyed by the mass media. The theory of the effects of mass media messages used in this paper are: cognitive effects, affective effects, behavioral effects. Cognitive effects occur when there is a change in what is known, understood or perceived by the audience. This effect relates to the transmission of knowledge, skills, beliefs or information. Which, when associated with sports, this effect is related to understanding the rules, reasoning related to tactics and strategy in matches.

To be successful in elite sports, it is very important to emphasize the psychological character. This is supported by several studies conducted by Coetzee et al. [30], Cox etc. [31] and Elferink-Gemser [32]. Sports performance as an evaluation situation is a situation that is influenced by emotional and cognitive factors [33, 34]. Therefore, the personal characteristics as well as the situational and cultural goals of the athlete are factors that must be considered [35]. Because there is a relationship between psychological characteristics and sports performance in elite players. So athletes need help from coaches and support personnel to create a supportive climate rather than overthinking media responses about 'mistakes' being reported to the public. [36].

While the affective effect arises when there is a change in what is felt as liked or hated by the audience. These effects are related to emotions, attitudes or values. In sports, the athlete's emotions have a very big influence on the athlete's mentality. If the athlete's emotions are greatly aroused, there will be a disturbance in his intellectual functions which results in the appearance or game of the athlete being chaotic. The influence of emotional disturbances does not only occur in the ability to function in the intellectual aspect but is also followed by physical changes, such as breathing, heart rate, and so on. One of the effects of mass media on the affective effect is on the physical aspect. Where the mass media highlight the condition of certain athletes to be able to achieve certain beauty standards or physical standards that can make them more popular and supported by the audience. [37-39].

This media pressure is stronger for female athletes and this can lead to very high levels of frustration [40, 41]. This can cause some athletes to develop eating disorders, in which athletes feel pressured to continue to lose weight in response to cultural standards set by society when they have to perform in sporting events. The attitude of society caused by the media, of course, has a negative impact because it can create feelings of discrimination against those who are less privileged. In the same way, research conducted by Kennard et al. [42] and Li'cen et al. [43], identified that subjective opinions expressed by commentators can directly influence audience behavior, in particular increasing sympathy or disapproval of a particular team by increasing feelings of euphoria before winning and losing. This shows that mass media can change people's behavior and personality when watching sports matches.

And for behavioral effects refer to real behavior that can be observed which includes patterns of actions, activities or habits of behavior. Actions or activities carried out can occur as a learning process in Bandura analysis. During the competition there are certain behaviors that are often repeated by athletes and eventually become a habit in preparation for victory. This can happen either intentionally or unintentionally, as it is a kind of superstition. These types of actions performed on a regular basis can lead to higher levels of concentration and motivation throughout the competition. So it is very important for athletes to maintain a controllable routine [44].

There is also the influence given by the mass media on the acquisition of healthy living habits after reading news about health or sports. Research conducted by Gao [45] shows that there is a good attitude towards involvement in sports after students are exposed to sports news. Similar findings, research conducted by Gietzen et al. [46] and Li et al [47], confirmed that viewers were motivated to be able to improve their habits after watching well-known entities do physical exercise and consume a balanced diet. Likewise, showing off an athlete's personal life can help maintain positive feelings about one's involvement in physical activity and sport [48]. This feeling of empathy is a key factor in promoting healthy habits after watching, hearing or seeing news delivered in the mass media.

Therefore, mass media experts and responsible individuals should try to cover different sporting events and introduce the sport and the champions to the public. Sports media must be able to reveal facts (strengths and weaknesses) by complying with ethics. In addition, the mass media can also play a good role in informing the development of cultures in sports such as the events of various sports championships. The mass media can also help the development of sports by creating programs to find sports talent and mentally motivate athletes who are competing in national and international events. In addition, managers, coaches, athletes and referees can take advantage of the role of the mass media to promote their sport to the public through publications that can be done in the mass media. 


\section{CONCLUSION}

The results showed that the mass media can affect sports achievement. Sports and mass media have a symbiotic relationship or interdependence relationship. The main task of sports media is to convey sports messages. Sports media must create a championship sports culture in society. Sports media publish championship sports culture taking into account the national sports system and the ethical principles of mass media. For further research, it is recommended to be able to conduct a more complete analysis of the effects of mass media on sports by looking at the characteristics of the sport or by analyzing the effects of mass media based on gender.

\section{ACKNOWLEDGMENT}

The author would like to thank the athletes, coaches and national badminton administrators who have made it easy to obtain data and assisted in collecting data on the effects of mass media on sports performance. Hopefully the results of this research can be useful in helping the development of sports achievements in general and badminton sports achievements in particular.

\section{REFERENCES}

[1] Beck D. Media Representation: Sports. Int Encycl Media Eff 2017; 1-9.

[2] Bosshart DB and L. Sport and media. Routledge Handb Sociol Sport 2015; 22: $377-$ 387.

[3] Montín JM. Educar en el deporte a través de la TV. Comunicar 2008; 16: 517-521.

[4] Lee JH, Choi YJ. News values of sports events: An application of a newsworthiness model on the World Cup coverage of US and Korean media. Asian J Commun 2009; 19: 302-318.

[5] Moscoso Sánchez D, Fernández Gavira J, Pérez Flores A. The media construction of the sports' elite from the European perspective: an analysis of the European Symposium of Sports 2010. Sport Soc 2018; 21: 516-528.

[6] Sherwood M, Nicholson M. Who controls sport news? Media relations and information subsidies in Australian sport media. Media Int Aust 2017; 165: 146-156.

[7] Bryant AAR and J. Handbook of Sports and Media. Taylor \& Francis e-Library, 2006.

[8] Wenner LA. Media, Sport \& Society. Newbury Park. California: Sage, 1989.

[9] JJ. C. Sports and the Media. In: Sport in
Society: Issues and Controversies. Boston: McGraw-Hill, 2004.

[10] Blain, N., Boyle, R., \& O'Donnell H. Sport and national identity in the European media. London: Leicester University Press., 1993.

[11] Brookes R. Representing Sport. London: Arnold, 2002.

[12] Zbigniew D, Krzysztof W. J, Michał L, et al. Mass Media and Professional Sport. Balt $J$ Heal Phys Act 2013; 4: 284-294.

[13] Wanta W. Reflections on Communication and Sport: On reporting and Journalists. Commun Sport 2013; 1: 76-87.

[14] Eagleman A. Stereotypes of Race and Nationality: A qualitative Analysis of Sport Magazine Coverage of MLB players. J Sport Manag 2011; 25: 156-168.

[15] Brown NA, Billings AC. Sports fans as crisis communicators on social media websites. Public Relat Rev 2013; 39: 74-81.

[16] Koerber D, Zabara N. Preventing damage: The Psychology of Crisis Communication buffers in Organized Sports. Public Relat Rev 2016; 43: 193-200.

[17] Devlin, M.; Brown N. Using Personality and Team Identity to Predict Sports Media Consumption. Int J Sport Commun 2017; 10: 371-392.

[18] Singer J. User-generated Visibility: Secondary Gatekeeping in a Shared Media Space,. New Media Soc 2014; 16: 55-73.

[19] Sherwood, M.; Nicholson M. Web 2.0 platforms and the work of newspaper sport journalists. Journalism 2013; 14: 942-959.

[20] Maguire JA GA. Mass Media and the Rise of Professional Sports. Encyclopedia Britannica.

[21] J. G. Sport as entertainment: the role of mass Communications. Critical Readings: Sport, Culture and Media. Maidenhead: Open University Press, 2004.

[22] Hornik R YI. Using theory to design evaluations of communication campaigns: the case of the National Youth Anti-Drug Media Campaign. Commun Theory, 2003.

[23] Shank MD. Sports Marketing: A Strategic Perspective. Upper Saddle River,. NJ. London: Prentice HalL, 2002.

[24] Horne J. Sport and the mass media in Japan. Sociol Sport J 2005; 22: 415-432.

[25] Tatiana F, Carvalho PG. Media influence on elite football performance: a literature review to develop a model. J Phys Educ Sport 2018; 
18: 1980-1985.

[26] Gulam A (2016). Role of mass media in sports communication. Int $J$ Adv Educ Res 2016; 5: 51-53.

[27] Bellamy R V. "Sports media: A modern institution". In Handbook of sports and media. Hillsdale: Lawrence Erlbaum., 2006.

[28] Nazemi Y, Khoshemehr AH. Media and its impact on sports. Int J Sport Stud 2012; 2: 624-630.

[29] Singh M. Effect of media in developing sports. 2016; 3: 470-471.

[30] Coetzee, B., H. Grobbelaar and CG. "Sport Psychological Skills That Distinguish Successful From Less Successful Soccer Teams." J Hum Mov Stud 2006; 51: 383 401.

[31] Cox HR. Sport Psychology Concepts and Application. Dubuque: Wm.C. Brow Publisherhttps://books.google.co.id/books?id =D9_YDwAAQBAJ\&pg=PA369\&lpg=PA36 $9 \& d q=$ Prawirohardjo, + Sarwono. $+2010 .+$ Buk $\mathrm{u}+$ Acuan+Nasional+Pelayanan+Kesehatan++ Maternal+dan+Neonatal.+Jakarta+:+PT+Bina + Pustaka+Sarwono+Prawirohardjo.\&source= bl\&ots=riWNmMFyEq\&sig=ACfU3U0HyN3 I (2002).

[32] Elferink-Gemser M. “Today's Talented Youth Field Hockey Players, The Stars of Tomorrow? A Study on Talent Development in Field Hockey." Holanda: Groningen University., 2005.

[33] Hook, J. N., D.P. Valentiner and JC. "Performance and Interaction Anxiety: Specific Relationships With Other- and SelfEvaluation Concerns." Anxiety, Stress Coping An Int J 2013; 26: 203 - 216.

[34] Howle, T. C. and RCE. "The Effect of Induced Self-Presentation Concerns on Cognitive Appraisal and Affect." Anxiety, Stress Coping an Int J 2013; 26: 700-710.

[35] Fletcher, D. and MS. "Psychological Stress in Sports Coaches: A Review of Concepts, Research, and Practice." . J Sports Sci 2010; 28: 127-137.

[36] Kristiansen, E. , Hanstad, D. V., and Roberts GC. Coping with the Media at The Vancouver Winter Olympics: "We All Make a Living Out of This". J Appl Sport Psychol 2011; 23: 443-458.

[37] Cranmer, G.; Bowman, N.; Goldman Z. A
Preliminary Study of Racialized Brawn and Brain Framing Effects. Commun Res Rep 2017; 34: 78-83.

[38] Stirling, A.; Cruz, L.; Kerr G. Influence of Fetirement on Body Satisfaction and Weight Control Behaviors: Perceptions of elite rhythmic gymnasts. J Appl Sport Psychol 2012; 24: 129-143.

[39] Francisco, R.; Narciso, I.; Alarcao M. Parental Influences on elite aesthetic Athletes' Body Image Dissatisfaction and Disordered Eating. J Child Fam Stud 2013; 22: 10821091.

[40] Swami, V.; Steadman, L.; Tovée M. A comparison of Body Size Ideals, Body Dissatisfaction, and Media Influence Between Female Track athletes, Martial Artists, and Non-athletes. Psychol Sport Exerc 2009; 10: 609-614.

[41] Godoy-Pressland. A. 'No hint of bulging muscles': The surveillance of sportswomen's bodies. British print media. Journalism 2016; 744-759.

[42] Kennard, M.; McLellan T. M. A. Sports Media Representations of Concussions in the National Rugby League. Aust Psychol; 53,: 97-102.

[43] Li cen, S.; Topi c M. The Imbalance of Commentators' Discourse During a Televized Basketball Match. Kinesiology; 40,: 61-68.

[44] Kristiansen E., G.C. Roberts and FEA. "Achievement involvement and stress coping in elite wrestling." Scand Med Sci Sport 2008; 18: 526-538.

[45] Gao J. Influences of Image Communication Paradigm of Sports Information on Sports Behavior of University Students. Asian Soc Sci 2012; 8: 243-249.

[46] Gietzen, M.; Gollust, S.; Linde, J.; NeumarkSztainer, D.; Eisenberg M. A Content Analysis of Physical Activity in TV Shows Popular Among Adolescents. Res $Q$ Exerc Sport 2017; 88: 72-82.

[47] Li, K.; Sotiriadou, P.; Auld C. An Examination of The Role of Sport and Leisure on The Acculturation of Chinese Immigrants. World Leis J 2015; 57: 209-220.

[48] Albalawi, Y.; Sixsmith J. Identifying Twitter influencer profiles for health promotion in Saudi Arabia. Heal Promot Intern; 456-463. 